\title{
Aeromonas and Plesiomonas species from scarlet ibis (Eudocimus ruber) and their environment: monitoring antimicrobial susceptibility and virulence
}

\author{
Débora Souza Collares Maia Castelo-Branco - Aline Lobão da Silva • \\ Frederico Ozanan Barros Monteiro • Glaucia Morgana de Melo Guedes • \\ Jamille Alencar Sales · Jonathas Sales de Oliveira · José Erisvaldo Maia Junior • \\ Stefânia Araújo Miranda · José Júlio Costa Sidrim • Lucas Pereira de Alencar • \\ Raimunda Sâmia Nogueira Brilhante • Rossana de Aguiar Cordeiro • \\ Tereza de Jesus Pinheiro Gomes Bandeira • Waldemiro de Aquino Pereira Neto • \\ Marcos Fábio Gadelha Rocha
}

Received: 13 June 2016/Accepted: 14 September 2016/Published online: 24 November 2016

(C) Springer International Publishing Switzerland 2016

\begin{abstract}
The present study aimed at evaluating the role of captive scarlet ibises (Eudocimus ruber) and their environment as reservoirs of Aeromonas spp. and Plesiomonas spp., and analyzing the in vitro antimicrobial susceptibility and virulence of the recovered bacterial isolates. Thus, non-lactose and weak-lactose fermenting, oxidase positive Gram-negative bacilli were recovered from cloacal samples $(n=30)$ of scarlet ibises kept in a conservational facility and from water samples $(\mathrm{n}=30)$ from their environment. Then, the antimicrobial susceptibility, hemolytic activity and biofilm production of the recovered Aeromonas spp. and Plesiomonas shigelloides strains were
\end{abstract}

D. S. C. M. Castelo-Branco - G. M. M. Guedes ·

J. S. Oliveira - J. J. C. Sidrim · L. P. Alencar .

R. S. N. Brilhante $(\bowtie) \cdot$ R. A. Cordeiro .

T. J. P. G. Bandeira - W. A. Pereira Neto ·

M. F. G. Rocha

Department of Pathology and Legal Medicine,

Postgraduate Program in Medical Microbiology, Federal University of Ceará, Rua Coronel Nunes de Melo s/n, Rodolfo Teófilo, Fortaleza, Ceará CEP 60430-270, Brazil e-mail: brilhante@ufc.br

A. L. Silva · J. A. Sales · J. E. Maia Junior ·

M. F. G. Rocha

School of Veterinary Medicine, Postgraduate Program in Veterinary Sciences, State University of Ceará, Fortaleza, Ceará, Brazil assessed. In addition, the virulence-associated genes of Aeromonas spp. were detected. Ten Aeromonas veronii bv. sobria, 2 Aeromonas hydrophila complex and 10 P. shigelloides were recovered. Intermediate susceptibility to piperacillin-tazobactam and cefepime was observed in 2 Aeromonas spp. and 1 P. shigelloides, respectively, and resistance to gentamicin was observed in $4 P$. shigelloides. The automated susceptibility analysis revealed resistance to piperacillintazobactam and meropenem among Aeromonas spp. and intermediate susceptibility to gentamicin among P. shigelloides. All Aeromonas isolates presented hemolytic activity, while $3 P$. shigelloides were non-

\author{
F. O. B. Monteiro \\ Universidade Federal Rural da Amazônia - UFRA, \\ Belém, Pará, Brazil \\ S. A. Miranda \\ Parque Mangal das Garças, Belém, Pará, Brazil \\ T. J. P. G. Bandeira \\ School of Medicine, Christus College - Unichristus, \\ Fortaleza, Ceará, Brazil
}


hemolytic. All Aeromonas spp. and 3/10 P. shigelloides were biofilm-producers, at $28{ }^{\circ} \mathrm{C}$, while 10 Aeromonas spp. and 6/10 P. shigelloides produced biofilms, at $37{ }^{\circ} \mathrm{C}$. The most prevalent virulence genes of Aeromonas spp. were asal and ascV. Scarlet ibises and their environment harbour potentially pathogenic bacteria, thus requiring monitoring and measures to prevent contamination of humans and other animals.

Keywords Eudocimus ruber Scarlet ibis . Aeromonas sp. Plesiomonas shigelloides. Antimicrobial susceptibility · Virulence factor

\section{Introduction}

The scarlet ibis (Eudocimus ruber) is a tactile foraging, colonial wading bird that breeds in coastal regions and mangroves. Studies on this species are scarce and mainly focus on their behavioral and reproductive habits, with a lack of data on the health of these animals. Considering the importance of birds as hosts and carriers of potentially pathogenic bacteria, studying the bacterial microbiota of clinically healthy wild birds is important to understand the epidemiology of bacterial diseases that can affect not only birds themselves but also other animals and humans (Kim et al. 2015).

Among the bacteria with zoonotic importance, Aeromonas spp. and Plesiomonas shigelloides are notable, and are found in a wide variety of habitats. These microorganisms have been described as components of the microbiota of ectothermic animals and waterfowl and are reported as important animal pathogens, especially for fish (Janda and Abbott 2010; Kim et al. 2015; Janda et al. 2016). In humans, Aeromonas spp. and $P$. shigelloides are important waterborne and foodborne pathogens, causing acute diarrhea, or causing extraintestinal infections affecting several internal organs, as well as skin and soft tissues. These infections are more commonly described in food handlers and aquaculture professionals (Janda and Abbott 2010; Parker and Shaw 2011; Janda et al. 2016).

The pathogenesis of Aeromonas infections is yet to be clearly understood, but several virulence factors have been proposed, such as hemolysins, enterotoxin, and type III secretion systems, which have been detected in strains recovered from animals and water sources (Castelo-Branco et al. 2015). On the other hand, virulence factors of $P$. shigelloides have not been fully elucidated, however the presence of plasmids, cytolysins, hemolysins, enterotoxins, including cholera-like toxins, has been reported (Janda et al. 2016). In addition, the production of biofilms by members of these bacterial genera is associated with their survival and maintenance in the environment and the animal host, hence, this ability is considered an important virulence trait (Igbinosa 2014; Dobiasova et al. 2014). Moreover, it is worth emphasizing that biofilm growth is associated with seafood colonization, which increases the risk of foodborne infections with these pathogens (Mizan et al. 2015).

Therefore, the present study aimed at evaluating the role of captive scarlet ibises (E. ruber) and their environment as reservoirs of Aeromonas spp. and Plesiomonas spp., and analyzing the in vitro antimicrobial susceptibility and virulence of the recovered bacterial isolates.

\section{Materials and methods}

\section{Ethics}

This project was approved by the Authorization and Information System for Biodiversity (SISBIO) of the Chico Mendes Institute for Conservation of Biodiversity (ICMBio, Brazil), under the license No. 45009-1. It was also approved by the Ethics Committee for the Use of Animals (CEUA) of the State University of Ceará, under the protocol number 4797437/2014.

\section{Animal handling}

For the isolation of microorganisms, cloacal samples were collected from scarlet ibis (E. ruber) kept in captivity at Parque Mangal das Garças, located in Belém, State of Pará, Brazil (S: $1^{\circ} 27^{\prime} 51.9^{\prime \prime}$ and W: $48^{\circ} 30^{\prime} 19 \cdot 9^{\prime \prime}$ ). All animals were clinically evaluated and their body score was assessed, classifying them as obese, normal or thin (Ritchie et al. 1994). Animals that were clinically ill and/or those that were obese or thin were not sampled for this research. Three sample collections were carried out with an interval of 1 month between them. At each collection point, ten animals (30 animals in total) were randomly captured 
with pole nets to collect biological material. These animals were kept in three enclosures. In the enclosure of Aningas (Sector 1), a closed and collective enclosure, scarlet ibises cohabit with other species and were fed with fish and specific extruded bird ration for ibises and flamingoes. On the island of scarlet ibises (Sector 2), scarlet ibises live in semi-freedom along with other bird species and they receive only extruded feed. In the extra sector (Sector 3), where the surplus scarlet ibises of the Park intended for exchange with other zoos were kept, the birds receive only extruded feed. All three enclosures had a water tank/ponds and a proper ambiance to provide well-being and stimulate reproduction and nesting. All animals were daily assisted by a veterinarian and a biologist.

\section{Sample collection of biological material}

For each collection, cloacal samples $(n=10)$ were collected with sterile cotton swabs, which were inserted and rotated 180 degrees twice (Silva et al. 2004). Afterwards, the swabs were placed in Cary Blair transport medium (Silva et al. 2004). Water samples $(\mathrm{n}=10)$ were collected from ten different points of two artificial lakes that surround the island of scarlet ibises. These lakes receive water from the Guamá River. For this purpose, sterile Falcon tubes were used, dipped rapidly from 15 to $30 \mathrm{~cm}$ below the water surface. The tubes were immediately sealed with plastic film around the lid, and kept refrigerated until processing (Castelo-Branco et al. 2015).

\section{Sample processing}

Samples were processed at the Laboratory of Emerging and Re-emerging Pathogens (LAPERE) of the Federal University of Ceará and were kept under refrigeration until processing, within $24 \mathrm{~h}$ after collection. Cloacal swabs were transferred to tubes with $1 \mathrm{~mL}$ of sterile saline $(0.9 \% \mathrm{NaCl})$ and homogenized with a vortex mixer for $3 \mathrm{~min}$ and left to decant for $30 \mathrm{~min}$ at room temperature (Filiú et al. 2002). Water samples were processed in duplicate, distributing 2500 $\mu \mathrm{L}$ in each tube. Then, these aliquots were centrifuged at $3000 \mathrm{rpm}$ for $20 \mathrm{~min}$. After centrifugation, $2000 \mu \mathrm{L}$ of supernatant from each tube were discarded and the remaining volume of the tubes was mixed and sterile saline $(0.9 \% \mathrm{NaCl})$ was added to reach a final volume of $2000 \mu \mathrm{L}$. The solution was homogenized with a vortex mixer and left to settle out for $30 \mathrm{~min}$ at room temperature (Medeiros 2008). Finally, $10 \mu \mathrm{L}$-aliquots of the supernatant from each cloacal and water sample were seeded in duplicate on MacConkey agar and thiosulphate citrate bile and sucrose (TCBS) agar. The plates were incubated at $35^{\circ} \mathrm{C}$ for $24-48 \mathrm{~h}$.

\section{Bacterial isolation and identification}

The colonies grown on the agar plates were counted and non-lactose and weak-lactose fermenting colonies on MacConkey medium were selected for screening, as well as the colonies grown on TCBS medium. First, a Gram stain of the selected colonies was performed to ensure that they were Gram-negative bacilli. Subsequently, they were tested for cytochrome oxidase production, ability to ferment and oxidize glucose, gas production from D-glucose, indole production and ability to grow on TCBS agar (Winn et al. 2006). Pseudomonas aeruginosa ATCC 27853 and Escherichia coli ATCC 25922 were used as quality control to validate the biochemical tests. The screening was performed based on established identification keys, following specific methodology for Aeromonas spp. and P. shigelloides (Winn et al. 2006). After the biochemical screening, the strains were subjected to automated biochemical identification, using the Vitek 2 system (bioMerieux), with Gram-negative identification cards. In these analyses, reference ATCC strains were also included, as recommended by the manufacturer, as well as previously identified Aeromonas and Plesiomonas strains. Only results with a probability level above $95 \%$ were considered reliable (Castelo-Branco et al. 2015).

In vitro antimicrobial susceptibility testing

These analyses were performed through broth microdilution and automated methods (Vitek $2^{\mathrm{TM}}$ ), for comparative purposes. The antimicrobial drugs used in broth microdilution susceptibility testing were selected according to the document M45-A2 (CLSI 2010). The minimum inhibitory concentrations (MIC) of piperacillin-tazobactam, cefepime, ceftazidime, meropenem, gentamicin and ciprofloxacin (Sigma Chemical Corporation, USA) against strains of Aeromonas spp. and $P$. shigelloides were determined through broth microdilution (document M07-A9, CLSI 2012). These assays were performed in 
Mueller-Hinton broth (Difco, USA) with a final bacterial inoculum of $5 \times 10^{5} \mathrm{UFC} / \mathrm{mL}$ (CLSI 2010). Drug-free and bacterium-free wells were included as growth and sterility controls, respectively. The plates were incubated at $35^{\circ} \mathrm{C}$ for $18-20 \mathrm{~h}$ (CLSI 2012). MICs were considered to be the lowest drug concentration capable of inhibiting $100 \%$ of bacterial growth and the isolates were classified as susceptible (S), intermediate (I) and resistant (R), according to M45-A2 document (CLSI 2010). E. coli ATCC 25922 and $E$. coli ATCC 35218 were included in each test, as quality control (CLSI 2010).

For the automated analyses, the antimicrobial susceptibility card N-239 (bioMérieux, France) was used and all procedures were carried out according to the manufacturer's recommendations (Castelo-Branco et al. 2015). E. coli ATCC 25922 and E. coli ATCC 35218 were included as quality control (CLSI 2010).

Hemolytic activity of Aeromonas spp.

and $P$. shigelloides

The hemolytic activity of the 12 Aeromonas spp. and $10 P$. shigelloides isolates was evaluated, based on the methodology described by Yano et al. (2015). For such, bacterial colonies were suspended in $2 \mathrm{~mL}$ of sterile saline, until reaching a turbidity of 6 on McFarland scale. Afterwards, $10 \mu \mathrm{L}$ of each bacterial inoculum were seeded on $5 \%$ sheep blood agar and the plates were incubated at $37{ }^{\circ} \mathrm{C}$ for $48 \mathrm{~h}$. Isolates were classified as $\beta$-hemolytic, when complete hemolysis was observed, characterized by the presence of clear halos surrounding the bacterial colonies; $\alpha$ hemolytic, when partial hemolysis was observed, characterized by the presence of greenish halos surrounding the colonies, and non-hemolytic, when hemolysis was not observed. One strain of Streptococcus pyogenes and one Streptococcus sanguinis were included as controls for complete and partial hemolysis, respectively.

Biofilm production by Aeromonas spp. and $P$. shigelloides

The biofilm production of Aeromonas spp. and $P$. shigelloides was evaluated at two different temperatures $\left(28\right.$ and $37^{\circ} \mathrm{C}$ ). For this, the strains were subcultured on brain heart infusion agar (BHI) and incubated at $37^{\circ} \mathrm{C}$ for $24 \mathrm{~h}$. Then, a bacterial suspension was prepared in saline solution, reaching turbidity equivalent to 6 on McFarland scale. In parallel, 96-well flat-bottomed polystyrene microtiter plates were prepared by adding $175 \mu \mathrm{L}$ of BHI broth supplemented with $1 \%$ glucose (Bandeira et al. 2013). Afterwards, $25 \mu \mathrm{L}$ of the bacterial suspension were added to each well, and the plates were incubated at 28 or $37^{\circ} \mathrm{C}$, for $48 \mathrm{~h}$ (Bandeira et al. 2013; CasteloBranco et al. 2015). Three wells were used as negative growth control. Assays were carried out in triplicate at two different moments. After incubation, the supernatant was carefully aspirated from the wells, followed by three washes with PBS-Tween. Then, the wells were washed with $100 \mu \mathrm{l}$ of $100 \%$ methanol. After drying, $100 \mu \mathrm{L}$ of a $0.3 \%$ crystal violet solution were added. After $20 \mathrm{~min}$, the crystal violet was removed, and the wells were washed twice with $200 \mu \mathrm{L}$ of sterile distilled water. Then, $150 \mu \mathrm{L}$ of $33 \%$ acetic acid solution was added to the stained wells and left for $30 \mathrm{~s}$. The acetic acid was, then, transferred to another 96-well polystyrene plate, which was read through spectrophotometry at a wavelength of $540 \mathrm{~nm}$. The optical density values obtained at $540 \mathrm{~nm}($ OD540 nm) were corrected by subtracting the OD540 $\mathrm{nm}$ obtained for the negative control (containing only RPMI 1640 broth). The cutoff point $(\mathrm{ODc})$ for biofilm production was defined as three standard deviations above the mean OD540 nm obtained for the negative control. At the end, all the tested strains were classified according to Stepanovic et al. (2000), as non-biofilm producers (OD540 nm $\leq$ ODc), weak producers (ODc $<$ OD540 $\mathrm{nm} \leq 2 \times$ ODc), moderate producers $(2 \times$ ODc $<$ OD540 $\mathrm{nm}$ $\leq 4 \times$ ODc $)$ and strong producers $(4 \times$ ODc $<$ OD540 nm).

For the microscopic analyses of Aeromonas spp. and $P$. shigelloides biofilms, two strains of Aeromonas spp. (1 A. veronii sobria and 1 A. hydrophila complex, both biofilm producers from water) and two $P$. shigelloides (both biofilm producers from water) were initially grown in a 24-well polystyrene plate containing a thermanox coverslide at the bottom of the well. Afterwards, the same methodology described for biofilm formation was used, adjusting the total volume of culture medium to $1000 \mu \mathrm{L}$. After $48 \mathrm{~h}$ of incubation, biofilms were evaluated through confocal and fluorescence microcopy. For the confocal microscopic analysis, the methodology described by CasteloBranco et al. (2015) was used. The thermanox coverslides were transferred to glass-bottomed Petri 
dishes and $200 \mu \mathrm{L}$ of the Live/Dead (Invitrogen ${ }^{\mathrm{TM}}$ ) fluorescent dye was added. Afterwards, the coverslides were evaluated under a Confocal Microscope Nikon C2, at $488 \mathrm{~nm}$ for the detection of the SYTO9 fluorescent dye, which identifies live bacterial cells, and at $561 \mathrm{~nm}$ for the detection of the propidium iodide, which identifies dead bacterial cells. Z-stack images were obtained from five fields for each of the analyzed strains. Software COMSTAT was used for quantitative analysis of the image stacks produced by CLSM (Heydorn et al. 2000). The evaluated parameters were: total biomass, biomass average thickness, total average thickness, roughness coefficient and surface-volume ratio, whereas thresholding was calculated automatically by Otsu's method.

Detection of virulence genes of Aeromonas spp. encoding for type III secretion system, hemolysin and enterotoxin

DNA extraction was performed using a Wizard Genomic DNA Purification Kit (Promega, USA), according to the manufacturer's instructions. The concentration and purity of extracted products were measured, using Qubit ${ }^{\circledR}$ (Invitrogen, Carlsbad, USA). The detection of virulence factors was performed through conventional PCR using primers designed for Aeromonas spp. In order to detect the genes encoding enterotoxin ( $a c t$ ), haemolysin (asal), and type III secretion system (ascV) in strains of Aeromonas spp., the following primers were used: $\left(5^{\prime}-3^{\prime}\right)$ act_FAGAAGGTGACCACCAAGAACA and $a c t$ R-AAC TGACATCGGCCTTGAACTC (Kingombe et al. 1999), asa-1_F-TAAAGGGAAATAATGACGGCG and $a s a$ 1_R-GGCTGTAGGTATCGGTTTTCG (Wang et al. 2003), and $a s c V$ F-CTCGAACTGGAAGAGCAGA ATG and $a s c V \_$R-GAACATCTGGCTCTCCTTCTC GATG (Martino et al. 2011). PCR amplification was performed in a final volume of $25 \mu \mathrm{L}$, as described by Castelo-Branco et al. (2015). The PCR conditions were performed according to Martino et al. (2011), with an initial denaturation of $2 \mathrm{~min}$ at $94{ }^{\circ} \mathrm{C}$ followed by 35 cycles of $20 \mathrm{~s}$ at $94{ }^{\circ} \mathrm{C}, 30 \mathrm{~s}$ at $56{ }^{\circ} \mathrm{C}$ for the genes asal and $a c t$ and $60{ }^{\circ} \mathrm{C}$ for $a s c V$ gene, $50 \mathrm{~s}$ at $72{ }^{\circ} \mathrm{C}$ and a final extension at $72{ }^{\circ} \mathrm{C}$ for $7 \mathrm{~min}$.

PCR products were visualized on $1.8 \%$ agarose gel, through an UV transilluminator. The specific products of the genes act (enterotoxin), asal (hemolysin) and ascV (type III secretion system) were 232, 249 and $577 \mathrm{bp}$, respectively. A molecular weight marker of $100 \mathrm{bp}$ was included in order to analyze amplicon size. As positive control, a strain of A. hydrophila whose genes have been previously detected was included, and as negative control, PCR Mix without DNA sample was used (Castelo-Branco et al. 2015).

\section{Statistical analysis}

Mann-Whitney test was used for the comparison of the antimicrobial MIC values against Aeromonas spp. and $P$. shigelloides strains. Concerning biofilm production, the crystal violet absorbance values obtained for Aeromonas spp. and P. shigelloides incubated at both tested temperatures were compared through Student's T test. This same test was used to compare the biofilm production by Aeromonas spp. and $P$. shigelloides. Finally, Pearson's Chi square test and Fisher's exact test were applied to compare the categorical data between species and the presence of virulence genes. P-values lower than $5 \%$ indicate significant conclusion.

\section{Results}

Overall, 22 non-lactose or weak-lactose fermenting, oxidase positive Gram-negative bacilli were recovered: 12 Aeromonas spp. (2 Aeromonas hydrophila complex and 10 Aeromonas veronii bv. sobria) from water and $10 \mathrm{P}$. shigelloides from cloacal swabs $(n=7)$ and water samples $(n=3)$ (Table 1). The highest number of isolates was obtained from water samples (15/22), followed by cloacal samples (7/22). Aeromonas spp. were only recovered from water samples, while $P$. shigelloides was more frequently recovered from cloacal samples $(\mathrm{P}=0.0031)$ than water.

All Aeromonas spp. isolates were susceptible to ceftazidime, cefepime, meropenem, ciprofloxacin and gentamicin. Two strains of $A$. veronii bv. sobria presented intermediate susceptibility to piperacillintazobactam (MIC: $32 / 4 \mu \mathrm{g} / \mathrm{mL}$; Table 2). Concerning $P$. shigelloides, all strains were susceptible to ceftazidime, meropenem, ciprofloxacin and piperacillintazobactam, but four strains were resistant to gentamicin (MIC: $16 \mu \mathrm{g} / \mathrm{mL}$ ), and two had intermediate 
Table 1 Isolation and identification of Aeromonas spp. and P. shigelloides from scarlet ibis and water

\begin{tabular}{|c|c|c|c|c|c|}
\hline \multicolumn{6}{|l|}{ Isolation } \\
\hline Collection & $\begin{array}{l}\text { Origin and site } \\
\text { (n) }\end{array}$ & $\begin{array}{l}\text { Gram negative } \\
\text { non/weak-lactose } \\
\text { fermenting }\end{array}$ & $\begin{array}{l}\text { Oxidase } \\
\text { producer }\end{array}$ & $\begin{array}{l}\text { Screening for } \\
\text { Aeromonas and } \\
\text { Plesiomonas }\end{array}$ & $\begin{array}{l}\text { Identification } \\
\text { (n) }\end{array}$ \\
\hline \multirow[t]{2}{*}{$1 \mathrm{st}$} & Cloaca $(\mathrm{n}=10)$ & 22 & 9 & 4 & P. shigelloides (4) \\
\hline & Water $(\mathrm{n}=10)$ & 13 & 8 & 7 & $\begin{array}{l}\text { A. veronii bv. sobria (6) } \\
\text { A. hydrophila complex (1) }\end{array}$ \\
\hline \multirow[t]{2}{*}{ 2nd } & Cloaca $(\mathrm{n}=10)$ & 50 & 20 & 3 & P. shigelloides (3) \\
\hline & Water $(\mathrm{n}=10)$ & 25 & 5 & 4 & $\begin{array}{l}\text { A. veronii bv. sobria (2) } \\
\text { P. shigelloides }(2)\end{array}$ \\
\hline \multirow[t]{2}{*}{3 rd } & Cloaca $(n=10)$ & 22 & 2 & 0 & - \\
\hline & Water $(\mathrm{n}=10)$ & 21 & 15 & 4 & $\begin{array}{l}\text { A. veronii bv. sobria (2) } \\
\text { A. hydrophila complex (1) } \\
\text { P. shigelloides (1) }\end{array}$ \\
\hline Total & & & & & 22 \\
\hline
\end{tabular}

(-) No isolated strains

susceptibility to this drug (MIC: $8 \mu \mathrm{g} / \mathrm{mL}$ ). Furthermore, it was observed that a gentamicin resistant strain from water showed intermediate susceptibility to cefepime (MIC: $16 \mu \mathrm{g} / \mathrm{mL}$; Table 2). Gentamicin showed higher MIC values against $P$. shigelloides than Aeromonas spp. $(\mathrm{P}=0.001)$, whereas piperacillin-tazobactam $\quad(P=0.002), \quad$ ceftazidime $(\mathrm{P}=0.0188)$ and meropenem $(\mathrm{P}=0.0072)$ showed higher MIC values against Aeromonas spp. than $P$. shigelloides.

The automated susceptibility analysis presented an overall good agreement level with the broth microdilution method, but some disagreements were observed. Vitek 2, for instance, demonstrated five and six Aeromonas spp. strains resistant to piperacillin-tazobactam (MIC: $\geq 128$ ) and meropenem (MIC: $\geq 16$ ), respectively, and three $P$. shigelloides strains with intermediate susceptibility to gentamicin (Table 2).

Concerning the hemolytic activity, all Aeromonas isolates were positive, with 7/12 $\beta$-hemolytic and 5/12 $\alpha$-hemolytic isolates. As for $P$. shigelloides, $7 / 10$ were $\alpha$-hemolytic, $3 / 10$ were non-hemolytic and no $\beta$ hemolytic isolates were observed.

Regarding biofilm production, when it was analyzed at $28{ }^{\circ} \mathrm{C}$, all isolates of Aeromonas spp. were positive for the production of biofilms (5 weak and 7 moderate biofilm-producers), while only three $P$. shigelloides isolates produced biofilms ( 3 weak producers). When the assays were performed at $37^{\circ} \mathrm{C}, 2$ isolates of $A$. veronii bv. sobria were non-biofilm producers and the remaining isolates were weak producers, while 6/10 P. shigelloides were biofilm-producers ( 5 weak and 1 moderate biofilm producer). The production of biofilm by Aeromonas spp. at $28{ }^{\circ} \mathrm{C}$ was statistically higher $(\mathrm{P}<0.05)$ than that at $37^{\circ} \mathrm{C}$, while the opposite was observed for $P$. shigelloides, i.e., biofilm production was enhanced at the higher temperature $(\mathrm{P}<0.05)$. When comparing both bacterial genera, Aeromonas spp. presented a statistically higher biofilm $(\mathrm{P}<0.05)$ production than $P$. shigelloides at $28{ }^{\circ} \mathrm{C}$, but not at $37^{\circ} \mathrm{C}$.

The analyses of the biofilm structures, through confocal microscopy, revealed that Aeromonas spp. biofilms presented a total biomass of $10.1 \pm 3.12$ $\mu \mathrm{m}^{3} / \mu \mathrm{m}^{2}$; a biomass average thickness of $21.54 \pm 3.7$ $\mu \mathrm{m}$, a total average thickness of $19.94 \pm 5.03 \mu \mathrm{m}$; a roughness coefficient of $0.34 \pm 0.28$ and surfacevolume ratio of $1.59 \pm 0.19 \mu^{2} / \mu \mathrm{m}^{3}$ (Fig. 1a). As for $P$. shigelloides, biofilms presented a biomass of $9.16 \pm 5.29 \mu \mathrm{m}^{3} / \mu \mathrm{m}^{2}$; a biomass average thickness of $22.97 \pm 5.59 \mu \mathrm{m}$, a total average thickness of $20.07 \pm 8.16 \mu \mathrm{m}$; a roughness coefficient of $0.43 \pm$ 0.32 and surface-volume ratio of $1.72 \pm 0.35 \mu \mathrm{m}^{2}$ / $\mu \mathrm{m}^{3}$ (Fig. 1b).

The detection of a single virulence gene was observed in three strains of $A$. veronii bv. sobria (1/ 12 act, 1/12 asal and 1/12 ascV), while the occurrence of more than one gene was observed in eight strains $(6$ 


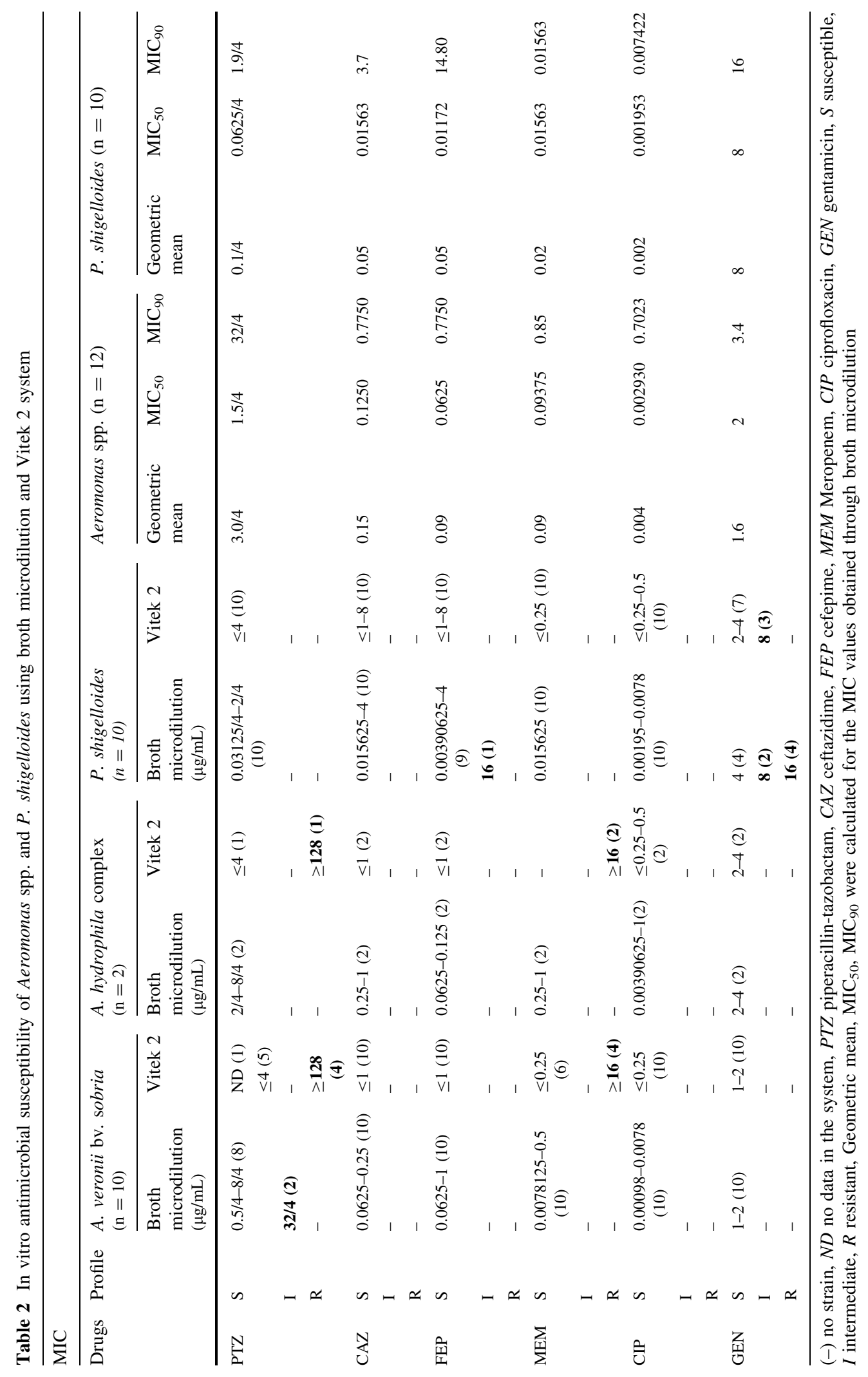




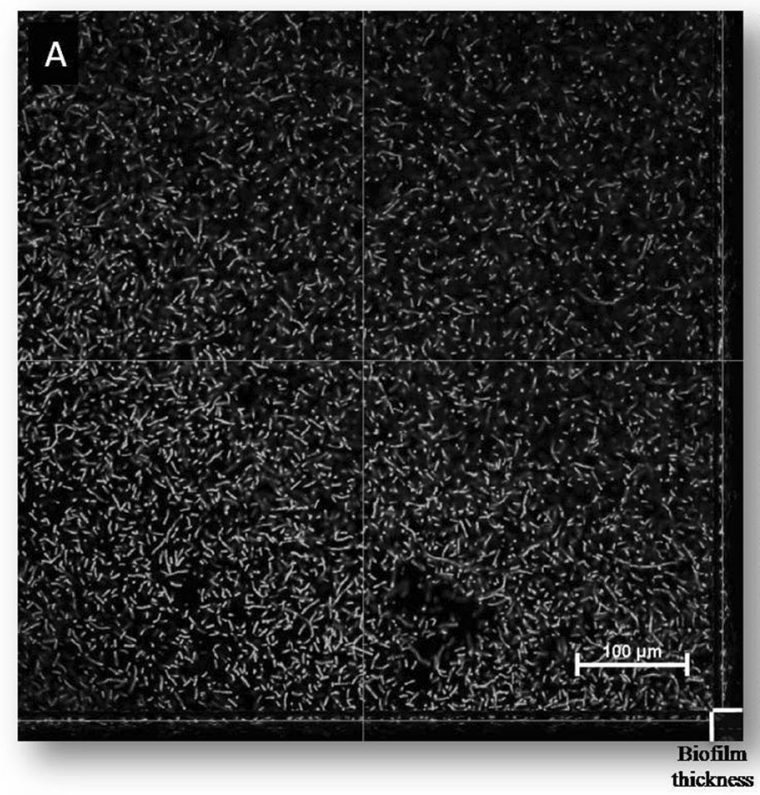

Fig. 1 Representative images of Confocal Laser Scanning Analysis of mature biofilms of Aeromonas spp. (a) and $P$. shigelloides (b). Note the more homogenous distribution of

A. veronii bv. sobria, 2 A. hydrophila complex). The asc $V$ gene (type III secretion system) was the most detected virulence gene in Aeromonas spp. $(\mathrm{P}=0.0391)$, which was observed in nine strains, while the asal gene (hemolysin) was detected in eight strains and the act gene (enterotoxin) was detected in three strains of Aeromonas spp. Regarding the detection of more than one virulence gene per strain, the most frequent combination was asc $V$ and asal $(\mathrm{P}=0.0107)$, detected in six A. veronii bv. sobria. Only one strain of $A$. hydrophila complex simultaneously showed the three virulence genes, and one strain of $A$. veronii bv. sobria did not show any of the tested genes.

\section{Discussion}

Members of the genera Aeromonas and Plesiomonas have been described as components of the microbiota of ectothermic animals and aquatic birds and are considered potentially pathogenic for these animals and humans, causing waterborne diseases or infections by traumatic inoculation (Janda and Abbott 2010; Kim et al. 2015, Janda et al. 2016). These observations

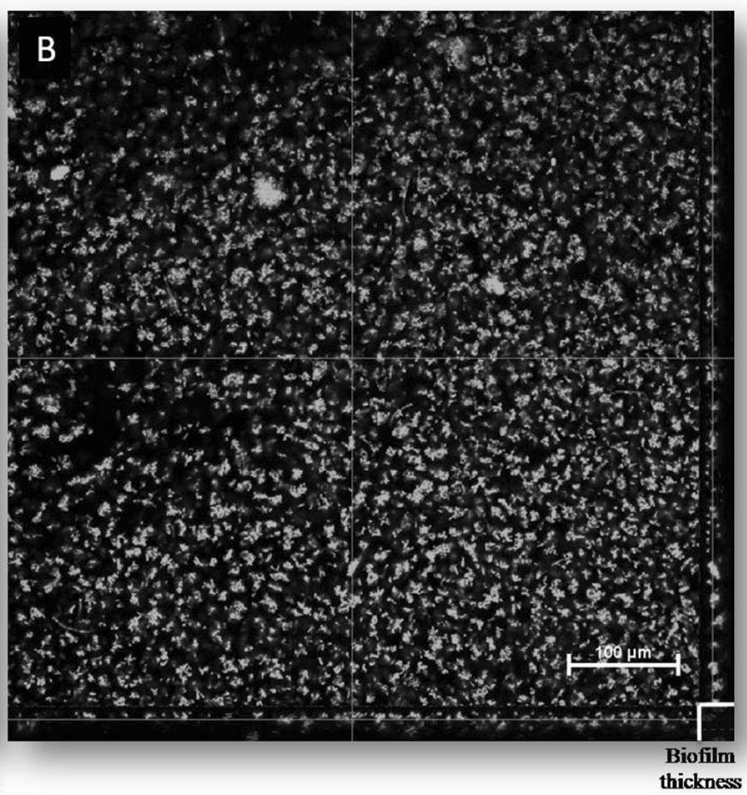

Aeromonas cells and the decreased thickness of biofilm structure, when compared to that of $P$. shigelloides. Magnification of $\times 400$, images generated with $488 \mathrm{~nm}$ laser (SYTO9)

reinforce the importance of monitoring different aquatic environments for the presence of these microorganisms, their antimicrobial susceptibility and pathogenic potential. In this study, Aeromonas spp. were isolated from water samples, while $P$. shigelloides was isolated from water samples and cloacal swabs obtained from scarlet ibis. These results demonstrate that scarlet ibis can act as reservoirs of this pathogen, possibly because of their feeding habits, i.e., fish and crustaceans. To our knowledge, this is the first time these waterborne pathogens were recovered from captive scarlet ibises and their habitat, emphasizing that conservational facilities should be constantly monitored for the presence of these pathogens, in order to promote human, animal and environmental health.

The identification of the recovered isolates was based on conventional biochemical screening, for genus identification, followed by biochemical identification through the system Vitek 2, which contains Aeromonas species and $P$. shigelloides in its database. All of the results presented high probability of success (above $95 \%$ ), and reference ATCC strains were included in order to validate the identification cards. In a previous study, the identification of Aeromonas 
with Vitek 2 presented accuracy above $80 \%$, when compared to the molecular identification (Lamy et al. 2010). Even though molecular techniques have been applied, this biochemical method is routinely and widely used in clinical laboratories and it has also been used in other researches (Igbinosa 2014; Tang et al. 2014). However, phenotypic methods are mostly not sufficient to identify the species within the different Aeromonas species complex (Janda and Abbot 2010), therefore, they were not specified in the present research. As for Plesiomonas, a recent review discussed that $P$. shigelloides shows remarkably little strain-to-strain variation in its biochemical profile, thus, this species is easily identified through conventional tests (Janda et al. 2016).

Water is the major source of contamination with Aeromonas spp. or $P$. shigelloides and an important vehicle for the spread of these microorganisms (Kim et al. 2015). Water sources and aquatic ecosystems also contribute for the environmental dissemination of antimicrobial drugs that are indiscriminately used in farming practices, especially, aquaculture, contributing for the emergence of resistant bacterial strains, which are a public health problem worldwide (Wellington et al. 2013). In this study, intermediate susceptibility to piperacillin-tazobactam among strains of $A$. veronii bv. sobria and resistance to gentamicin and intermediate susceptibility to cefepime among strains of $P$. shigelloides were observed. Intermediate susceptibility indicates that resistance mechanisms have been acquired and resistant bacterial strains may soon emerge. The antimicrobial susceptibility was also assessed through the automated method Vitek 2 and disagreements between both methods were observed. However, broth microdilution is the gold standard method for antimicrobial susceptibility testing.

Phenotypic virulence traits of Aeromonas spp. and $P$. shigelloides were also assessed and, overall, Aeromonas spp. produced more virulence factors than $P$. shigelloides, as observed by the higher hemolytic activity and biofilm-forming ability of the former. Considering these bacterial genera, especially Aeromonas spp., are colonizers of aquatic environments and ectothermic animals and capable of causing infections in endothermic animals, two incubation temperatures were tested for biofilm production, i.e. 28 and $37^{\circ} \mathrm{C}$. Aeromonas spp. produced more biofilm than $P$. shigelloides, especially at $28^{\circ} \mathrm{C}$. The enhanced biofilm formation by Aeromonas spp. at this temperature suggests the importance of this feature for bacterial survival and maintenance in the environment and within ectothermic hosts (Scoaris et al. 2008), contributing for the bacterial colonization of seafood, hence, the occurrence of foodborne infections (Mizan et al. 2015).

The confocal biofilm analyses showed that Aeromonas biofilms were flatter and more homogenously organized than those of $P$. shigelloides, with bacterial cells more closely arranged to each other. In addition, $P$. shigelloides biofilms presented a higher surfacevolume ratio and a larger external surface than those of Aeromonas spp. These structural characteristics, associated with the crystal violet assay, suggest that the biofilms of Aeromonas spp. are more closely distributed, with more packed cells and less pores and voids within the biofilm, than those of $P$. shigelloides, as shown by the higher biomass values and lower biomass average thickness (Heydorn et al. 2000; Schaber et al. 2007). It is important to highlight that to our knowledge this is the first systematic characterization of the biofilm-forming ability of $P$. shigelloides and the first confocal structural analysis of Aeromonas and Plesiomonas biofilms.

Moreover, virulence genes of Aeromonas spp. were also investigated, and the ascV (type III secretion system) and asal (hemolysin) genes were the most frequently detected genes, corroborating previous researches (Wang et al. 2003; AravenaRomán et al. 2012). For P. shigelloides, no specific primers have been developed for the PCR-based detection of virulence genes and only phenotypical analyses have been performed (Fariñas et al. 2005). Thus, the same primers used for the detection of virulence genes in Aeromonas spp. were tested with $P$. shigelloides, because of the similarities between these bacterial genera, but none of the PCR products were compatible with the size expected for these genes, confirming the identification performed by the Vitek 2 system and the specificity of these primers to the Aeromonas genus.

Finally, scarlet ibises and their environment harbour waterborne and foodborne bacterial pathogens for humans and other animals. Hence, these birds and their environments should be continuously monitored for the presence of these microorganisms and measures for the prevention of infections should be implemented in order to minimize the zoonotic risks 
for humans who handle these animals and visitors of zoological facilities.

Acknowledgements This work was supported by the National Council for Scientific and Technological Development (CNPq; Brazil; process: 445670/2014-2) and Coordination Office for the Improvement of Higher Education Personnel (CAPES; Brazil, Procad/Casadinho; process: 552215/2011-2). We thank Parque Mangal das Garças for allowing the performance of this research in their facility.

\section{Compliance with ethical standards See Methods.}

Conflicts of interest None.

\section{References}

Aravena-Román M, Inglis TJJ, Henderson B, Rilley TV, Chang BJ (2012) Antimicrobial susceptibilities of aeromonas strains isolated from clinical and environmental sources to 26 antimicrobial agents. Antimicrob Agents Chemother 569:1110-1112. doi:10.1128/AAC.05387-11

Bandeira TJPG, Moreira CA, Brilhante RSN, Castelo-Branco DSCM, Neto MP, Codeiro RA, Rodrigues TJ, Rocha MFG, Sidrim JJC (2013) In vitro activities of amoxicillin-clavulanate, doxucycline, ceftazidime, imipenem, and thimethoprim-sulfamethoxazole against biofilm of Brazilian strains of Burkholderia pseudomallei. Antimicrob Agents Chemother 57:5771-5773. doi:10.1128/AAC.00721-13

Castelo-Branco DSCM, Guedes GMM, Brilhante RSN, Rocha MFG, Sidrim JJC, Moreira JLB, Cordeiro RA, Sales JA, Riello GB, Alencar LP, Paiva MA, Vasconcelos DC, Menezes ISIS, Ponte YB, Sampaio CM, Monteiro AJ, Bandeira TJ (2015) Virulence and antimicrobial susceptibility of clinical and environmental strains of Aeromonas spp. from Northeastern Brazil. Can J Microbiol 61:597-601. doi:10.1139/cjm-2015-0107

CLSI (2010) Clinical and Laboratory Standards Institute, M45A2 Methods for antimicrobial dilution and disk susceptibility testing of infrequently isolated or fastidious bacteria; approved guideline-second edition. Clinical and Laboratory Standards Institute, Wayne

CLSI (2012) Clinical Laboratory Standards Institute. Methods for dilution antimicrobial susceptibility tests for bacteria that grow aerobically; Approved Standard-Nineth Edition; document M07-A9. Clinical and Laboratory Standards Institute, Wayne

Dobiasova H, Kutilova I, Piackova V, Vesely T, Cizek A, Dolejska M (2014) Ornamental fish as a source of plasmidmediated quinolone resistance genes and antibiotic resistance plasmids. Vet Microbiol 171:413-421. doi:10.1016/ j.vetmic.2014.02.011

Fariñas LB, Noblet DS, Arce MA, García H, Ramírez M, Cabrera LE, Fernández TA, Castañeda TN (2005) Estudio de factores de virulencia en cepas de $P$. shigelloides aisladas de animales domésticos y afectivos (Study of virulence factors in $P$. shigelloides isolated from domestic and affective animals). Rev Electrón Vet 10:1-12
Filiú WFOF, Wanke B, Agüena SM, Vilela VO, Macedo RCL, Lazera M (2002) Cativeiro de aves como fonte de Crytococcus neoformans na cidade de Campo Grande, Mato Grosso de Sul, Brasil. Rev Soc Bras Med Trop 35:591-595. doi:10.1590/S0037-86822002000600008

Heydorn A, Nielsen AT, Hentzer M, Sternberg C, Givskov M, Ersboll BK et al (2000) Quantification of biofilm structures by the novel computer program COMSTAT. Microbiology 146:2395-2407. doi:10.1099/00221287-146-10-2395

Igbinosa IH (2014) Antibiogram profiling and pathogenic status of Aeromonas species recovered from chicken. Saudi J Biol Sci 21:481-485. doi:10.1016/j.sjbs.2014.06.003

Janda JM, Abbott SL (2010) The genus Aeromonas: taxonomy, pathogenicity and infection. Clin Microbiol Rev 23:35-73. doi:10.1128/CMR.00039-09

Janda JM, Abbott SL, McIver CJ (2016) Plesiomonas shigelloides revisited. Clin Microbiol Rev 29:349-374. doi:10. 1128/CMR.00103-15

Kim K, Lee S, Kwak D (2015) Prevalence, biochemical characteristics, and antibiotic susceptibility of Aeromonas, Vibrio, and Plesiomonas isolated from different sources at a zoo. J Zoo Wildl Med 46:298-305. doi:10.1638/20140194R.1

Kingombe CIB, D’Aoust JY, Huys G, Hofmann L, Rao M, Kwan J (1999) PCR detection, characterization, and distribution of virulence genes in Aeromonas spp. Appl Environ Microbiol 65:5293-5302

Lamy B, Laurent F, Verdier I, Decousser JW, Lecaillon E, Marchandin H, Roger F, Tigaud S, De Montclos H, COLBVH Study Group, Kodjo A (2010) Accuracy of 6 commercial systems for identifying clinical Aeromonas isolates. Diagn Microbiol Infect Dis 67:9-14. doi:10.1016/ j.diagmicrobio.2009.12.012

Martino ME, Fasolato L, Montemurro F, Rosteghin M, Manfrin A, Patarnello T, Novelli E, Cardazzo B (2011) Determination of microbial diversity of Aeromonas strains on the basis of multilocus sequence typing, phenotype, and presence of putative virulence genes. Appl Environ Microbiol 77:4986-5000. doi:10.1128/AEM.00708-11

Medeiros AO, Kohler LM, Hamdan JS, Missagia BS, Barbosa FA, Rosa CA (2008) Diversity and antifungal susceptibility of yeasts from tropical freshwater environments in Southeastern Brazil. Water Res 42:3921-3929. doi:10. 1016/j.watres.2008.05.026

Mizan FR, Jahid IK, Ha S (2015) Microbial biofilms in seafood: a food-hygiene challenge. Food Microbiol 49:41-55. doi:10.1016/j.fm.2015.01.009

Parker JL, Shaw JG (2011) Aeromonas spp. clinical microbiology and disease. J Infect 62:09-11. doi:10.1016/j.jinf. 2010.12.003

Ritchie BW, Harrison GJ, Harrison LR (1994) Avian medicine: principles and application. Wingers Publishing, Florida

Schaber J, Hammond A, Carty N, Williams S, Colmer-Hamood J, Burrowes B, Dhevan V, Griswold J, Hamood AJ (2007) Diversity of biofilms produced by quorum-sensing-deficient clinical isolates of Pseudomonas aeruginosa. J Med Microbiol 56:738-748. doi:10.1099/jmm.0.47031-0

Scoaris DO, Colacite J, Nakamura CV, Ueda-Nakamura T, Abreu Filho BA, Dias Filho BP (2008) Virulence and antibiotic susceptibility of aeromonas spp. isolated from drinking water. Antonie Van Leeuwenhoek 93:111-122 
Silva GM, Silva CMF, Bruno SF, Abreu DLC (2004) Enterobacteriaceae identification of the intestinal microbiota in laying hens (Gallus gallus Linnaeus, 1758) from Lohmann S.L.S. lineage. Rev Bras Ciênc Vet 11:153-155. doi:10. 4322/rbcv.2014.361

Stepanovic S, Vukovic D, Dakic I, Savic B, Svabic-Vlahovic M (2000) A modified microtiter-plate test for quantification of staphylococcal biofilm formation. J Microbiol Methods 49:175-179

Tang HJ, Lai CC, Lin HL, Chao CM (2014) Clinical manifestations of bacteremia caused by Aeromonas species in Southern Taiwan. PLoS One 9:e91642. doi:10.1371/ journal.pone.0091642

Wang G, Clark CG, Liu C, Pucknell C, Munro CK, Kruk TMAC, Caldeira R, Woodward DL, Rodgers FG (2003) Detection and characterization of the hemolysin genes in Aeromonas hydrophila and Aeromonas sobria by multiplex PCR. J Clin Microbiol 41:1048-1054. doi:10. 1128/JCM.41.3.1048-1054.2003

Wellington EMH, Boxall ABA, Cross P, Feil EJ, Gaze WH, Hawkey PM, Johnson-Rollings AS, Jones DL, Lee NM, Otten W, Thomas CM, Williams AP (2013) The role of the natural environment in the emergence of antibiotic resistance in gram-negative bacteria. The Lancet Infect Dis 13:155-165. doi:10.1016/S1473-3099(12)70317-1

Winn WC, Allen SD, Janda WM, Koneman EW, Procop GW, Schreckenberger PC, Woods GJ (2006) Color atlas and textbook of diagnostic microbiology. Lippincott Williams \& Wilkins, Philadelphia, p 1736

Yano Y, Hamano K, Tsutsui I, Aue-umneoy D, Ban M, Satomi M (2015) Occurrence, molecular characterization, and antimicrobial susceptibility of aeromonas spp. in marine species of shrimps cultured at inland low salinity ponds. Food Microbiol 47:21-27. doi:10.1016/j.fm.2014.11.003 